\title{
Highway Operation Management Mode Of New Ideas
}

\author{
Yang Wenqi ${ }^{1, a}$, Liu Guan ${ }^{1, b}$, Chen Tao ${ }^{1, c}$ \\ ${ }^{1}$ Graduate academy of Southwest Jiaotong University,Sichuan,Chengdu,610031, China

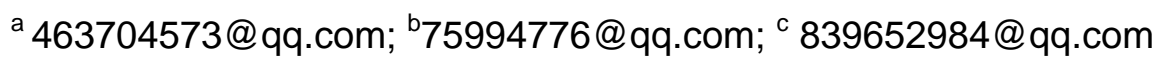

Key words: The highway; Operations management; Model; research

\begin{abstract}
The highway in our country starts relatively late. But with the rapid development of economy, the development of the highway is also growing. Its total mileage reached 65000 kilometers, the second largest in the world. However, rapid development cause several operation management problems and become seriously. So the study of highway operation management mode has the vital significance. In this paper, through the research of highway operation management design at home and abroad principles, norms and the corresponding management system sum up the design framework of highway operation mode and put forward a new train of thought providing a reference for future highway operating mode.
\end{abstract}

\section{Introduction}

The rapid development of Highway in our country makes a great contribution to society and economy, but it also causes other negative effects. Only under the scientific operation management, highway can give full play to its advantages. Therefore, we need to find a suitable operation management mode for Chinese situation. Through the study of highway operation management mode for a long time, this text sum up the basic idea of highway operating model design and put forward the new ideas of operation management.

\section{Foreign highway operation management pattern status}

The highway is the main mode of road transport in developed countries, which is playing a very important role in the process of economic development.

Japan $^{[1]}$ : By the national centralized management, which is divided into company, bureau, clearing house three-level management. The construction and tube on one body in company, but separate at local and institute. And the company type is the chartered company.USA ${ }^{[2]}$ : Each state unified management in concentration, which is divided into state, city, county three-level management of non-charge highway. The construction and tube are on one body. And the charge items are through chartered company, others through Business-orientation management.

Through further search and analysis, we can learn about the common features of foreign highway management: Firstly, governments play a leading role in highway construction and management. Secondly, Patterns are corresponding to the source of fund and the use of system. Thirdly, it has a set of relatively complete and mature laws and regulations in highway planning, investment and financing, construction, operations, earnings, supervision and management ${ }^{[3]}$.

\section{Chinese highway operation management status and exploration of new ideas}

China has different stage of highway development. The social system, facing problems and tasks are also different .But the highway has the common as a economic and social infrastructure. The management also has similarities. There are still many aspects worth learning and reference.

\section{Chinese highway operation organization status and the new idea}

Status: The quality of highway operate organization depends on a perfect mechanism. In China, the institution is divided into three categories: unitary, binary and polybasic management mechanism. New ideas: Separate administration and enterprises. Implement the operation management mode: The government actively transforms the functions to reduce administrative 
intervention of highway company management behavior to achieve a situation of enterprise independent operation. Separation of construction and management can realize the professional advantage. Only in this way the market mechanism of loan incentives can be realized and improve the use benefit of the highway and revitalize the stock assets of the highway. A case of highway rights value transfer: A highway in China use of loans to build, it has invested 3.07 billion yuan. It is planning to transfer the right of charge. By analyzing all kinds of traffic data, if the expected return is $10 \%$.Then we can get to 1.03257 Millions as the charging equity value ${ }^{[4]}$.Through the analysis we can draw a conclusion: Only fully recognize the rights of highway in the separation of ownership and management rights, we can realize scientific management, market-oriented operation, and make the highway towards a virtuous circle .

\section{The highway asset management status and the new idea}

Status: Our country has an increasingly large scale of highway assets, while management is very weak .New ideas: Strengthen the market competitiveness with the franchise mode. Establish a highway franchise company with construction, management and maintenance. Project host governments or affiliation provide a franchise agreement for the company which plays a role as a project of investors and operators arrange financing risk taking. Obtain profits within the limit time and finally transfer project to relevant government agencies according to the agreement. This mode perfects the incentive and constraint mechanism. Exert the maximum to operator's subjective initiative $^{[5]}$. An actual case of franchise highway project: Beijing on the second phase of highway road is approximately $47 \mathrm{~km}$. The China Railway Construction Corporation formed a project company with capital highway development limited company and cooperated in this project. It's a investment and financing reform breakthrough. 3.6 billion yuan have been introduced and the burden of government is reduced with the diversification of investment.

\section{Highway traffic safety administration status and the new idea}

Status: Safety management is an important content of expressway management. Many factors will affect the traffic safety problems. New ideas: Ruling by the competent authorities of transport and realize the unification and integration. The highway management institutions of the department in charge unified management of municipal, traffic safety, communication monitoring, charging, service, and maintenance. It overcomes the weak foundation in highway traffic safety, the large costs and low efficiency. Make management more unity and integrity. An actual case of highway traffic safety management: Administration of a state of Maryland operation center is a SHART hub system. The state is covered by the hub and satellite function. They send information based on the requirement and expert advice and allow management operations from several areas. In the control room monitoring of highway and arterial traffic, is realized by a control center for state traffic which greatly enhances the integrity and unity of management.

\section{Highway toll management status and the new idea}

Status: After years of practice, China has formed two kinds of freeway tolling management form, the business charge payment and enterprise management mode ${ }^{[6]}$. As the highway is built and connects to each other, the traditional network has seriously affected the smooth highway. New ideas: Scale management, the network plan. Highway networking charge, provides a good conditions for highway management, has become the inevitable trend of the current highway development in China. The scale of operation is the effective guarantee to reduce operating costs, improve the operation efficiency and service quality, which become the reform of the highway operation and management direction. The construction of highway networking toll in Guangdong: Guangdong province began to explore highway networking toll in 1997. The provincial government has done a lot of fruitful work. Until now the provincial networking road reached 650 kilometers, about a third of the province highway mileage. Open the card in the establishment of service outlets and open network of roads, which is convenient to drivers and improve the efficiency of the highway traffic. Drivers and relevant owner reflect fine. 
Status and requirements: Highway maintenance management should try to be quantitative, mechanization, specialization and socialization. New ideas: Unified management system, quality inspection system specification. Highway maintenance management involves wide and long duration. There are many uncertain factors. So maintenance management system should be centralized management, classification and reasonable layout. Guarantee of maintenance quality is an important part of the highway maintenance. It must be strict to the maintenance quality. The establishment of maintenance engineering quality, acceptance mechanism and the corresponding management measures makes the maintenance operations marketization and specialization.

\section{Monitoring, communications management}

Main task: Maintain the highway communication monitoring equipment along with the time in good condition is very important It can quickly make a response to various emergencies, and provide decision basis for managers. Jiangsu section of Shanghai-Nanjing highway traffic control system. The Jiangsu section highway is located in the economically developed Yangtze river. Particularly complex network in the south of the Yangtze River, hills landform and climatic conditions have affected the traffic safety seriously. Therefore, the highway built a box that has the advantages of high performance, more convenient means of detection, emergency telephone system, video surveillance, perfect testing numerical alarm function intuitive, dynamic news released timely, providing important software environment for the traffic safety.

The service of highway area management

Status: Through service settings the highway meets the demand of passengers' diet and vehicle safety requirements. While limited service area, insufficient function and service are widespread in China. New ideas: Innovate management mechanism to realize service area marketization. Fully develop of the local regional services based on the geographic conditions and economic development, provide local characteristics, make services area more competitive. The characteristics of the service area in Guangxi province and development. There are 42 service area of Guangxi highway. These service areas have parking service area, refueling, auto repair, catering, shopping and other basic services. Since 2006, the Guangxi administration of the highway administration implement an Administration - management - service area management center of three-level management way to rehabilitation and expansion of service facilities, achieved good results.

\section{Conclusion}

By studying the foreign highway operation management mode, summarizes the basic thought of design highway operation mode and the operation management of new ideas are put forward. In view of the current status, following suggestions are put forward in this paper: One, In-depth investigation and study, according to the local actual situation to study of operations management practical and operability. Two, design the feasible highway operation and management mode combined with different regional characteristics under the existing standard design. Three,implement all the details according to the needs of each department by department management with design as head, specification as a foundation .

\section{References}

[1] Xianwei Hu;The management problems and countermeasures of the highway transport operation supervision[J]. Market forums(2011) .

[2] Hui Zhang: The United States highway operation management manual [M]. People's traffic press (2009) .

[3] Boyu Wang ,Quan Zheng and Zhiguo Zhang: Comparative analysis of domestic and international highway asset management system [C] (1994).

[4] Zhiduo Fan: Discussion on the current management mode of highway in our country analysis [J]. With the quality of commodity. ( 2011).

[5] Sheng Xin: the research of highway management pattern [D]. Chang 'an university (2003).

[6] Honghong Zeng: Highway operation management guide [M]. People's traffic press. (2006) 